M. R. Merkulov, Junior Research Fellow, Shevchenko Institute of Literature of the National Academy of Sciences of Ukraine, Kyiv

\title{
PANTELEIMON KULISH AS A RESEARCHER OF WORKS BY KLYMENTIY ZINOVIIV
}

This paper is a review of the article by Panteleimon Kulish which is dealing to poetical inheritance of Klymentiy Zinoviiv. The latter was a Ukranian Baroque wtriter of XVII-XVIII centuries. Kulish published his review for the first time in 1859 in the magazine called "The Russian colloquy", later - in the magazine "Osnova" ("Basis") in 1861. These scholar shows us good skills in the field of historical and culture research, but at the same time he underestimates scholastic education and literature, he considers they were cut off from the real Ukrainian culture and Ukrainian folk. Kulish says Klymentii was a typical snob, whose writings was full of praise to rich and powerful persons and hatred against simple and poor people. The reasons of this position were Klymentii's studying in scholastic school and his desire to belong to the highest level of society. Despite these negative features Klymentii Zinoviiv's poems contain a lot of useful information about Ukrainian life of XVII-XVIII centuries. The article by Panteleimon Kulish contains some original thoughts and conclusions, but anyway his opinion is not objective. At the same time this review is a very important document helping to research the texts and biography of Klymentii Zinoviiv.

Keywords: poetry, travels, Baroque, criticism.

\section{УДК 821.161.2.Куліш}

О. В. Пилипей, канд. філол. наук, Київський національний університет імені Тараса Шевченка, Київ

\section{РЕЦЕПЦІЯ ПОСТАТІ П. КУЛІША У ТВОРЧИХ РОЗДУМАХ М. ХВИЛЬОВОГО ТА М. ЗЕРОВА}

Розглянуто літературно-мистецький прочес 20-30-х рp. ХХ сm., якому серед літературознавиів зростає інтерес до постаті П. Куліша. Саме у 20-ті роки до Української академії наук був переданий архів П. Куліша, який став серйозною документальною, джерельною базою для вивчення творів, літературно-критичних поглядів, світогляду цуього письменника.

Ключові слова: аристократизм, естетизм, європеїзм, листування, модернізм, памфлет.

Такою складною особистістю, як П. Куліш, цікавився неординарний і суперечливий письменник М. Хвильовий, який у 1920-ті рр. став продовжувачем ідеї інтеграції України в культурний 
простір Європи. Започаткувавши літературну дискусію 19251928 pp. й беручи в ній активну участь, М. Хвильовий висловлював своє бачення напрямку розвитку української літератури й закликав орієнтуватися на "психологічну Європу". У своєму памфлеті "Культурний епігонізм", що входить до циклу "Думки проти течії" (1925), М. Хвильовий назвав саме П. Куліша "ідеальним революціонером-громадянином", зазначивши: "Що ж до ідеального революціонера-громадянина, то більшого за Панька Куліша не знайти. Здається, тільки він один маячить світлою плямою з темного українського минулого. Тільки його можна вважати за справжнього європейця, за ту людину, яка наблизилась до типу західного інтелігента". М. Хвильовий заперечував думку відомого у 20-х рр. критика О. Дорошкевича про те, що П. Куліш $є$ представником так званної "чорної Європи": "I ми зовсім не розуміємо, чому тов. Дорошкевич уважає його за представника "чорної Європи", на наш погляд, це саме й є Європа червона". На думку М. Хвильового, "червоне" це символ боротьби". М. Хвильовий оцінює постать П. Куліша, його діяльність як прогресивну, подаючи історіософський аналіз: "Як у свій час національної війни були революційним, червоним явищем в історії людськості, так і Куліш для нашої країни був прогресивною, червоною Європою" [Хвильовий, 1991, с. 473].

Проте М. Хвильовий указує на причину недостатньої реалізованості П. Куліша, бо він "стикнувся 3 мертвою стіною культурного епігонізму тодішньої української інтелігенції, ми б, безперечно, не мали б таких вождів, які завжди плентались у хвості маси" [Хвильовий, 1991, с. 473]. Ці самі рефлексії М. Хвильовий повторює в листі до М. Зерова від 8 жовтня 1925 р.: «Що ж до науки, до політики й культури в широкому розумінні цього слова, то тут більшого за Куліша я не бачу. Здається, тільки він один маячить світлою плямою з темного минулого. Тільки його можна вважати за справжнього європейця, за ту людину, яка наблизилась до типу західного інтелігента. I на цій фігурі стикаються мої розходження з Дорошкевичем. I саме не етичного, а соціального порядку. Для мене Куліш є представник не "чорної Європи", а найчервонішої. Що ж таке це "червоне", спитає мене Дорошкевич? Відповідаю: це - символ боротьби, прогресу. Куліш, по суті, був 
ідеологом молодої буржуазії, і коли б він не стикнувся з мертвою стіною культурного епігонізму тодішньої укра[їнської] інтелігенції, ми б, безперечно, не мали б таких вождів, які завжди плентались у хвості маси. Як у свій час національної війни були революційним, червоним явищем в історії людськості, так і Куліш для нашої країни був прогресивною, червоною Свропою. [... Бо він наближається до згаданого нами європейського типу...» [Хвильовий, 1991, с. 863].

Слід зазначити, що із М. Зеровим М. Хвильовий листувався із середини 1923 р. до початку квітня 1926 р. Абсолютно різні за світоглядом, вихованням, ці митці в тодішньому українському літературознавстві вважалися ворогами по різні боки ідеологічних барикад. Проте М. Хвильового й М. Зерова зближували їхні погляди на розвиток української культури в європейському контексті. "Цей високий ідейний союз робить честь їм обом, бо обом - таким неподібним, але таким щирим і принциповим лицарями культури йшлося про святе" [Білокінь, 1990, с. 23].

Під час літературної дискусії 1925-1928 рр. М. Зеров підтримав орієнтацію на "психологічну Європу" М. Хвильового, всупереч примітивним вульгаризованим поглядам. Сам М. Зеров був переконаний в європейському контексті України. Про М. Хвильового як про свого однодумця М. Зеров писав, що "одно за тими його [Хвильового. - О. П.] статтями мусять признати всі, хто тільки мислить і почуває: це їх турботу й тривогу за майбутнє нашого письменства" [Білокінь, 1990, с. 23].

Говорячи про європейський напрям української літератури, обидва митці виокремлювали автора, якого вважали за єдиного європейця за всю історію літературної України - П. Куліша.

I М. Хвильового, і М. Зерова приваблювали в літературноестетичних поглядах П. Куліша його естетизм та індивідуалізм. М. Хвильовий, створюючи ВАПЛІТЕ як альтернативу масовізму в літературі 1920-х рр., відстоював думку про елітарність мистецтва. М. Зеров як неокласик сповідував принципи естетизму та індивідуалізму як основи поетичної творчості. Тому не дивно, що ці двоє митців захопилися постаттю П. Куліша. Як писав В. Стус 
у книзі "Феномен доби", присвяченій творчості П. Тичини, розглядаючи проблему митець і влада, назвав "першим революціонером нашої культури Панька Куліша... [...]. Саме він визначив той комплекс проблем нашого духовного життя, який [...] знову став актуальним на початку 20 століття і відкрижений червоним олівцем М. Зерова і М. Хвильового у часи літературної дискусії 1925-28 рр. Хвильовий наголошував на тих моментах, які з'ясовував для себе П. Куліш [...]" [Стус, 2015, с. 12].

М. Зеров у 1928 р. зазначав: "3 Кулішем боролися, полемізували, винуватили у відступництві" [Зеров, 1990, с. 186]. Проте П. Куліш викликав реакцію і цим самим спонукав до роздумів. У своїй праці "Від Куліша до Винниченка", присвяченій П. Кулішеві, М. Зеров наголошував на "непримиренності його громадсько-культурної позиції, що раз у раз зачіпала українське громадянство [...]. Кулішеві треба віддати заслужене: 3 нього був великий майстер дратувати українську громадську думку" [Зеров, 1990, с. 5].

До постаті П. Куліша М. Зеров звертався й у своїй художній творчості. Так, в одному із сонетів циклу "Культуртрегери" автор подає психологічний портрет поета:

Завзяттям віє від його промов,

I в очах - відблиск молодого жару,

відзначаючи його активну життєву й громадянську позицію. Про орієнтир П. Куліша на Європу М. Зеров говорить:

Він боре тупість і муругу лінь.

В Європі хоче "ставляти курінь",

Над творами культурників п'яніє [Зеров, 1993, с. 516].

Неокласику М. Зерову дуже близькими були "твори культурників".

Отже, складна, багатогранна, неоднозначна постать П. Куліша була цікавою для модерністів 20-х pp. ХХ ст. Концепція культурництва, європеїзму, естетизму, аристократизму духу П. Куліша імпонувала як пролетарському письменникові М. Хвильовому, так і неокласикові М. Зерову. Постать П. Куліша вийшла далеко за межі XIX ст., коли жив і творив митець. Рефлексії П. Куліша стали провісниками модерності ХХ ст., втіленням якої займалися М. Хвильовий та М. Зеров. 


\section{СПИСОК ВИКОРИСТАНИХ ДЖЕРЕЛ}

Білокінь С. Закоханий у вроду слів. М. Зеров - доля і книги / С. Білокінь. К., 1990. $-56 \mathrm{c}$.

Гальчук О. Поетичне осмислення Миколою Зеровим світової культурної спадщини / О. Гальчук // Дивослово. - 1997. - № 8. - С. 4-7.

Івашків В. Європейські фольклорні та літературні мотиви у творчості П. Куліша 1840-х років / В. Івашків // Вісн. Львів. ун-ту. Сер. філол. - 2007. - Вип. 41. - С. 3-15.

Зелік О. Пантелеймон Куліш у критичній рецепції М. Могилянського / О. Зелік // Філол. науки. - 2009. - Вип. 1. - С. 72-78.

Зеров М. Куліш / М. Зеров // Українське слово. - К., 1993. - 516 с.

Зеров М. Від Куліша до Винниченка / М. Зеров // Твори : у 2 т. / М. Зеров. К., 1990. - Т. 2. -601 с.

Могилянський М. П. О. Куліш у 90 роках (Листи й документи) / М. Могилянський // Червоний шлях. - 1925. - № 8. - С. 180-200.

Стус В. Феномен доби (сходження на Голгофу слави) / В. Стус. - К., 2015. - 12 с.

Хвильовий М. Думки проти течії / М. Хвильовий // Твори : у 2 т. / М. Хвильовий. - К., 1991. - Т. 2. -881 с.

\section{REFERENCES}

Bilokin S. Zakokhanyi u vrodu sliv. M. Zerov - dolia i knyhy / Bilokin. - Kyiv, 1990. $-56 \mathrm{~s}$.

Halchuk O. Poetychne osmyslennia Mykoloiu Zerovym svitovoi kulturnoi spadshchyny // Dyvoslovo. - 1997. - № 8. - S. 4-7.

Ivashkiv V. Yevropeiski folklorni ta literaturni motyvy u tvorchosti P. Kulisha 1840-kh rokiv // Visnyk Lvivskoho universytetu. Seriia filolohiia. - 2007. - Vyp. 41. - S. 3-15.

Zelik O. Panteleimon Kulish u krytychnii retseptsii M. Mohylianskoho // Filolohichni nauky. - 2009. - Vyp. 1. - S. 72-78.

Zerov M. Kulish / M. Zerov // Ukrainske slovo. - Kyiv, 1993. - 516 s.

Zerov M. Vid Kulisha do Vynnychenka / M. Zerov // Tvory : u 2 t. / M. Zerov. Kyiv, 1990. - T. 2.

Mohylianskyi M. P. O. Kulish u 90 rokakh (Lysty y dokumenty) / M. Mohylianskyi // Chervonyi shliakh. - 1925. - № 8. - S. 180-200.

Stus V. Fenomen doby (skhodzhennia na Holhofu slavy) / V. Stus. - Kyiv, 2015. - 12 s.

Khvylovyi M. Dumky proty techii / M. Khvylovyi // Tvory : u 2 t. / M. Khvylovyi. - Kyiv, 1991. - T. 2.

Стаття надійшла до редакції 1 1.11.19.

O. V. Pilipey, $\mathrm{PhD}$, Taras Shevchenko National University of Kyiv, Kyiv

\section{P. KULISH IN CREATIVE THINKING M. KHVILOVY AND M. ZEROV}

In the literary and artistic discourse of the 20-30's of the XX century. Interest in P. Kulish is growing among literary scholars. It was in the 1920s that the archive of P. Kulish was transferred to the Ukrainian Academy of Sciences, which became 
a serious documentary, source base for the study of works, literary-critical views, and outlook of this writer.

$P$. Kulish is considered to be one of the first Europeanists of Ukrainian culture to lay the foundation for the modern modern culture of the 1920s. For example, G. Grabovych called P. Kulish a driving force and the founder of the newest Ukrainian intellectual, critical thought and those dimensions of national consciousness that underlie it, and a key figure in the formation of modern Ukrainian culture. He quite rightly noted about P. Kulish M. Dragomanov: "... one of the Ukrainophiles hits the point of world, human culture, which will lift our people".

Keywords: reception, correspondence, pamphlet, Europeanism, aesthetism, aristocracy, modernism.

\section{УДК 821.161.2.09+398 (092)Куліш}

В. Ф. Погребенник, д-р філол. наук, проф., Національний педагогічний університет імені М. П. Драгоманова, Київ

\section{САМОБУТНІСТЬ ФОЛЬКЛОРИЗМУ ПОЕЗЇ̈ ПАНТЕЛЕЙМОНА КУЛІША 70-90-Х років ХІХ столітТЯ}

Стаття є спробою комплексного дослідження різноаспектних зв'язків поетичної творчості Пантелеймона Куліша з украӥнським фольклором, міфологією та уснопоетичною спадщиною інших народів світу. Досліджено ідейно-естетичні особливості опрацювання письменником мотивів, образів, символіки тощо народної творчості, напряму $і$ специфіки модифікаиї вказаних джерел, висвітлення рівнів і мистецької результативності асиміляиї фольклорно-міфологічних джерел в останні періоди літературноі діяльності письменника. Вивчено характер міжсистемної комунікацї літератури $i$ фольклору, специфіку "відфольклорного" письма мития, спрямованого на рецепчію народної поезї у власних творчих виявах, репрезентативність літературно опосередкованого Кулішем начіональнонародного світу й змінні риси індивідуально своєрідного авторського фольклоризму та міфологізму.

Ключові слова: фольклор, міфологія, міжсистемна взаємодія, художня асиміляція, символи.

Наукова проблема "література і народна творчість", давня і в кожному періоді письменства нова, актуальна як сама по собі, так i через зв'язок із широким колом теоретичних i естетичних питань: традицій і новаторства, національно-народної виразності мистецтва слова, його генології, розвитку художніх стилів 